\title{
PENGARUH KUALITAS PELATIHAN TERHADAP KINERJA SDM MELALUI KECERDASAN EMOSI DAN KOMUNIKASI TERAPEUTIK PADA PANTI PELAYANAN SOSIAL LANJUT USIA DINAS SOSIAL PROVINSI JAWA TENGAH
}

\author{
Nur Chibtiyah; Djoko Santoso \\ Djoko_Hw@usm.ac.id
}

Program Studi Magister Manajemen Uniuversitas Semarang,Semarang,Indonesia

\begin{tabular}{l} 
Info Artikel \\
\hline Sejarah Artikel: \\
Diterima \\
Disetujui \\
Dipublikasikan \\
\hline Keywords: \\
Quality of service; \\
emotional \\
intelligence; \\
therapeutic \\
communication; \\
service \\
performance
\end{tabular}

Sejarah Artikel:

Diterima

Disetujui

Dipublikasikan

Keywords:

Quality of service;

emotional

intelligence;

therapeutic

communication

performance

\begin{abstract}
Abstrak
Panti Pelayanan Sosial Lanjut Usia "Potroyudan" Jepara dan Panti Pelayanan Sosial Lanjut Usia "Turusgede" Rembang Jawa Tengah mempunyai tugas memberikan pelayanan kepada Lanjut Usia terlantar yang mempunyai karakteristik yang berbeda-beda, untuk itu diperlukan suatu keahlian untuk lebih bisa berkomunikasi lebih aktif. Metode penelitian yang digunakan dalam thesis ini adalah menggunakan pendekatan kuantitatif dengan desain ex post facto. Variabel dalam penelitian ini terdapat tiga variable bebas dan dua variabel, yaitu: kualitas pelatihan, kecerdasan emosi , komunikasi terapeutik, dan kinerja pelayanan. Dari hasil penelitian terdapat pengaruh signifikan antara kualitas pelatihan dengan kecerdasan emosi, artinya semakin ditingkatkan kualitas pelayanan maka akan semakin meningkat kecerdasarn emosi seseorang; ada pengaruh signifikan antara kualitas pelatihan dengan komunikasi terapeutik, artinya semakin ditingkatkan kualitas pelayanan, maka akan semakin meningkat pula komunikasi terapeutik seseorang; tidak ada pengaruh signifikan antara kecerdasan emosi dengan komunikasi terapeutik, artinya walaupun kecerdasan emosi ditingkatkan tidak akan mempengaruhi komunikasi terapeutik; pengaruh signifikan antara kualitas pelatihan dengan kinerja pelayanan, artinya jika kualitas pelatihan ditingkatkan akan semakin meningkat pula kinerja pelayanan; ada pengaruh signifikan antara kecerdasan emosi dengan kinerja pelayanan, artinya bila kecerdasan emosi ditingkatkan maka kinerja pelayanan juga akan meningkat; dan ada pengaruh signifikan antara komunikasi terapuetik dengan kinerja pelayanan, artinya jika komunikasi terapeutik ditingkatkan maka kinerja pelayanan juga akan meningkat pula.
\end{abstract}

\section{THE EFFECT OF TRAINING QUALITY ON HR PERFORMANCE THROUGH THERAPEUTIC EMOTION AND COMMUNICATION INTELLIGENCE IN THE CONTINUOUS SOCIAL SERVICES OF AGES IN CENTRAL JAVA PROVINCE}

\section{Abstract}

The Elderly Social Service House "Potroyudan" Jepara and the Aged Social Care Center "Turusgede" Rembang is a Social Service Home of Social Service 
of Central Java Province. The research method used in this thesis is using quantitative approach with ex post facto design. Variable in this research there are three independent variables and two variables, namely: training quality, emotional intelligence, therapeutic communication, and service performance. From the results of the study there is a significant influence between the quality of training with emotional intelligence, which means the increased quality of service will increase the intelligence of one's emotions; There is a significant influence between the quality of training and therapeutic communication, which means that the higher the quality of service, the more therapeutic communication will increase; There is no significant influence between emotional intelligence and therapeutic communication, meaning that although enhanced emotional intelligence will not affect therapeutic communication; A significant influence between the quality of training and service performance, meaning that if the quality of training is improved, the service performance will increase; There is a significant influence between emotional intelligence and service performance, meaning if the emotional intelligence is improved then the service performance will also increase; And there is significant influence between therapeutic communication with service performance, meaning if therapeutic communication is improved then service performance will also increase also. 


\section{PENDAHULUAN}

Perkembangan pembangunan kesejahteraan sosial dewasa ini diwarnai adanya perubahan paradigma pembangunan yang bergeser ke arah desentralistik dalam suasana otonomi daerah yang memberikan peran lebih besar kepada daerah Kabupaten/Kota sebagai pelaku utama pembangunan serta memberikan kewenangan yang seluas-luasnya untuk menyelenggarakan pembangunan dan mengurus rumah tangganya sendiri. Dinas Sosial Provinsi Jawa Tengah sebagai Satuan Kerja Perangkat Daerah (SKPD) teknis urusan wajib bidang sosial melaksanakan tugas pokok dalam penanganan terhadap Penyandang Masalah Kesejahteraan Sosial (PMKS). Prinsip To Help People To Help Them Selves (membantu masyarakat agar mampu membantu dirinya sendiri) dan semangat Tat Twam Asi (Aku adalah Engkau dan Engkau Adalah Aku) telah menjadi landasan fundamental dalam penyelenggaraan kesejahteraan sosial PMKS yang berorientasi pada proses memanusiakan manusia sehingga mampu melaksanakan fungsi sosial secara mandiri bagi kesejahteraan hidupnya.

Undang-Undang Nomor 11 Tahun 2009 tentang Kesejahteraan Sosial menjelaskan bahwa indikator keberhasilan pembangunan kesejahteraan sosial di Jawa Tengah adalah semakin berkurangnya populasi Penyandang Masalah Kesejahteraan Sosial (PMKS) dan meningkatnya peran aktif Potensi Sumber Kesejahteraan Sosial (PSKS), yang diimplementasikan melalui 2 (dua) model pendekatan yakni pendekatan berbasis kelembagaan (Panti Pelayanan Sosial Dan Rumah Pelayanan Sosial) dan yang berbasis masyarakat, melalui 4 (empat) pilar pelayanan kesejahteraan sosial yakni Jaminan Sosial, Rehabilitasi Sosial, Pemberdayaan Sosial dan Perlindungan Sosial

Dalam rangka mengantisipasi tuntutan perubahan dan penyesuaian diri pada organisasi, perlu dipersiapkan Sumber Daya Manusia (SDM) guna meningkatkan kapasitas dan kinerjanya untuk terus belajar melalui pembekalan, sikap maupun keterampilan. Sejalan dengan era desentralisasi, peningkatan kapasitas SDM terus berlangsung di semua unit. Begitu juga di lingkungan Dinas Sosial Provinsi Jawa Tengah khususnya di Balai Pelayanan Asuhan Anak Sunu Ngesti Tomo dalam menghadapi perubahan SOTK Berdasarkan Undang-Undang Nomor 23 Tahun 2014 dan Peraturan Pemerintah Nomor 18 Tahun 2016 serta Peraturan Gubernur Jawa Tengah Nomor 109 Tahun 2016 tentang Organisasi dan Tata Kerja Unit Pelaksana Teknis Dinas Sosial Provinsi Jawa Tengah menjadi Panti Pelayanan Sosial Lanjut Usia Potroyudan Jepara.

Sebagai konsekuensi dari tuntutan perubahan tersebut, penyiapan SDM pengelola Panti Pelayanan Sosial di semua linipun harus mampu memposisikan diri sebagai bagian yang tak terpisahkan dari pembangunan, agar dapat memenuhi tuntutan kebutuhan pelayanan sosial. Untuk keberhasilan ini sumber daya manusia yang potensial terutama dalam pelayanan dan penyantunan.

Kinerja adalah kemampuan kerja yang tampak dalam situasi dan kondisi kerja sehari-hari, sehingga dari beberapa katagori ini akan mampu menganalisa efektifitas pelaksanaan kinerja di Panti Pelayanan Sosial yang diembankan sesuai dengan kemampuan dan keterampilan yang dimilikinya. Setelah dilihat dari beberapa penilaian pelaksanaan tugas sesuai dengan skill yang dimiliki oleh pegawai yang ada di Panti Pelayanan Sosial, maka barulah dinilai efektif atau tidaknya tugas yang telah dilaksanakan.

Penelitian ini, akan membahas masalah kinerja pelayanan yang akan menjadi topik utama. Oleh karena itu, perlu dijelaskan terlebih dahulu mengenai apa yang 
dimaksud dengan kinerja. Terkait dengan pengertian kinerja, terdapat beberapa pendapat dari para tokoh, antara lain yaitu menyatakan bahwa: "kinerja adalah keberhasilan personel, tim, atau unit organisasi dalam mewujudkan sasaran strategik yang telah ditetapkan sebelumnya dengan perilaku yang diharapkan” (Mulyadi, 2007)

Dalam meningkatkan kinerja sumber daya manusia dipengaruhi oleh beberapa faktor diantaranya adalah komunikasi terapeutik. Komunikasi terapeutik adalah proses dimana pegawai menggunakan pendekatan terencana dalam mempelajari kliennya (Keltner, et all dalam Potter \& Perry, 2005). Komunikasi terapeutik ialah suatu interaksi interpersonal antara pegawai dan klien yang selama interaksi berlangsung pegawai berfokus pada kebutuhan khusus klien untuk meningkatkan pertukaran informasi yang efektif (Videback, 2008).

Komunikasi terapeutik adalah komunikasi yang dilakukan atau dirancang untuk tujuan terapi. Seorang penolong atau pegawai dapat membantu klien mengatasi masalah yang dihadapinya melalui komunikasi (Suryani 2005). Menurut Purwanto yang dikutip oleh (Mundakir 2006), komunikasi terapeutik adalah komunikasi yang direncanakan secara sadar, bertujuan dan kegiatannya dipusatkan untuk kesembuhan pasien. Pada dasarnya komunikasi terapeutik merupakan komunikasi profesional yang mengarah pada tujuan yaitu kinerja dalam penyembuhan pasien (Siti Fatmawati 2010).

Sementara itu dari sudut pandang yang berbeda mengenai pelatihan karyawan, dalam bukunya Mondy (2008) menjelaskan bahwa: "pada hampir setiap survey, pelatihan mendapat peringkat tiga besar tunjangan yang diinginkan para karyawan dari pemberi kerja mereka dan mereka akan mencari perusahaan-perusahaan yang akan memberi mereka perangkat untuk maju dalam profesi mereka". Hal tersebut menjelaskan bahwa kesempatan untuk mendapatkan program pelatihan kerja yang sesuai dengan pekerjaan dan profesi yang dijalani merupakan salah satu harapan yang diinginkan oleh karyawan. Cascio (2006) menerangkan bahwa training opportunities atau kesempatan bagi karyawan untuk mendapatkan program pelatihan menjadi salah satu kompensasi non-financial yang diharapkan karyawan.

Berbeda dengan penelitian terdahulunya penelitian yang berjudul pengaruh motivasi, pendidikan dan pelatihan terhadap kinerja guru dan pegawai di Yayasan AlMuslimin Dumai, Zuzwita (2010) menyatakan bahwa pendidikan dan pelatihan yang diikuti oleh guru dan pegawai, ternyata tidak berpengaruh signifikan terhadap kinerja guru dan pegawai di Yayasan Al-Muslimin Dumai. Dalam penelitiannya Nursanti (2014) menyatakan bahwa pelatihan memiliki nilai terendah untuk meningkatkan kinerja karyawan. Pelatihan yang dilatih oleh karyawan senior secara turun menurun mengalami stagnasi dalam cara kerja dan penyelesaian permasalahan, karyawan cenderung tidak berkembang.

Faktor lain yang mempengaruhi kinerja selain variabel kompetensi komunikasi terapeutik dan pelatihan kinerja juga dipengaruhi oleh kecerdasan emosi. Cadman et all (2001) mengungkapkan bahwa dengan kecerdasan emosional yang baik seseorang akan dapat bekerja secara aktif dalam tim, mengenali dan berespon terhadap terhadap perasaan sendiri dan orang lain secara tepat serta dapat memotivasi diri sendiri dengan orang lain

Kecerdasan Emosional (Goleman, 2005) menyatakan bahwa kemampuan akademik bawaan, nilai rapor, dan prediksi kelulusan pendidikan tinggi tidak memprediksi seberapa baik kinerja seseorang sudah bekerja atau seberapa tinggi sukses yang dicapainya dalam hidup. Lebih lanjut Goleman menyatakan bahwa seperangkat kecakapan khusus seperti empati, disiplin diri, dan inisiatif mampu membedakan 
orang sukses dari mereka yang berprestasi biasa-biasa saja, selain kecerdasan akal yang mempengaruhi keberhasilan orang dalam bekerja.

Panti Pelayanan Sosial Lanjut Usia "Potroyudan" Jepara dan Panti Pelayanan Sosial Lanjut Usia "Turusgede" Rembang merupakan Panti Pelayanan Sosial Dinas Sosial Provinsi Jawa Tengah. Panti Pelayanan Sosial Lanjut Usia "Potroyudan" Jepara dan Panti Pelayanan Sosial Lanjut Usia "Turusgede" Rembang mempunyai tugas memberikan pelayanan kepada Lanjut Usia terlantar yang mempunyai karakteristik yang berbeda-beda, untuk itu diperlukan suatu keahlian untuk lebih bisa berkomunikasi lebih aktif.

Sumber daya manusia Panti Pelayanan Sosial Lanjut Usia "Potroyudan" Jepara dan Panti Pelayanan Sosial Lanjut Usia "Turusgede" Rembang, hampir semua kurang memiliki kompetensi ilmu pekerja sosial sehingga untuk melaksanakan pekerjaan di Panti Pelayanan Sosal Lanjut Usia kurang sesuai dengan Standar Operasional Prosedur (SOP) yang sudah ada.

Untuk memberikan pelayanan yang baik kepada Lanjut Usia diperlukan kecerdasan emosi dan komunikasi terapeutik agar lebih bisa mendalami apa yang dirasakan oleh penerima manfaat, sehingga para Lanjut Usia mampu mencurahkan sebuah keluh kesah yang dirasakan sehingga nantinya muncul kedekatan secara emosi antara penerima manfaat dengan pemberi pelayanan. Memberikan pelayanan yang baik kepada Lanjut Usia diperlukan kecerdasan emosi dan komunikasi terapeutik agar lebih bisa mendalami apa yang dirasakan oleh penerima manfaat, sehingga para Lanjut Usia mampu mencurahkan sebuah keluh kesah yang dirasakan sehingga nantinya muncul kedekatan secara emosi antara penerima manfaat dengan pemberi pelayanan.

\section{Perumusan Masalah}

Dengan melihat dari latar belakang di atas maka terlihat bahwa kinerja SDM Panti Pelayanan Sosial Lanjut Usia Dinas Sosial Provinsi Jawa Tengan masih belum sesuai dengan standar yang telah ditetapkan, hal ini karena skill/ pendidikan pegawai Panti Pelayanan Sosial Lanjut Usia Dinas Sosial Provinsi Jawa Tengan tidak sesuai dengan kinerja pelayanan yang ada, apabila hal ini tidak segera diselesaikan maka akan mengurangi kinerja pelayanan Panti Pelayanan Sosial Lanjut Usia Dinas Sosial Provinsi Jawa Tengan, hal ini bisa diselesaikan dengan memberikan pelatihan kepada pegawai Panti Pelayanan Sosial Lanjut Usia Dinas Sosial Provinsi Jawa Tengah.

Program pendidikan dan pelatihan menjadi salah satu pendekatan yang dilakukan perusahaan untuk meningkatkan kinerja karyawan. Mondy (2008) menjelaskan bahwa pelatihan memberi para pembelajar pengetahuan dan keterampilan yang dibutuhkan untuk pekerjaan mereka saat ini. Sudut pandang yang berbeda mengenai pelatihan karyawan, Dumai, Zuzwita (2010) menyatakan bahwa pendidikan dan pelatihan yang diikuti oleh guru dan pegawai, ternyata tidak berpengaruh signifikan terhadap kinerja guru dan pegawai. Berdasarkan latar belakang fenomena dan research gap maka rumusan masalah penelitian ini adalah bagaimana meningkatkan kinerja pelayanan pada Panti Pelayanan Sosial lanjut Usia "Potroyudan" Jepara. 


\section{TELAAH PUSTAKA}

\section{Pengertian Kinerja}

Tingkat keberhasilan suatu kinerja meliputi aspek kuantitatif dan kualitatif. Sedangkan, menurut Siswanto (dalam Muhammad Sandy, 2015) kinerja ialah prestasi yang dicapai oleh seseorang dalam melaksanakan tugas dan pekerjaan yang diberikan kepadanya. Rivai (dalam Muhammad Sandy, 2015) memberikan pengertian bahwa kinerja atau prestasi kerja adalah hasil atau tingkat keberhasilan seseorang secara keseluruhan selama periode tertentu di dalam melaksanakan tugas dibandingkan dengan berbagai kemungkinan, seperti standar hasil kerja, target atau sasaran atau kriteria yang telah ditentukan terlebih dahulu dan disepakati bersama.

Pengertian kinerja menurut Moeheriono (2012) yaitu "Kinerja atau performance merupakan gambaran mengenai tingkat pencapaian pelaksanaan suatu program kegiatan atau kebijakan dalam mewujudkan sasaran, tujuan, visi dan misi organisasi yang dituangkan melalui perencanaan strategis suatu organisasi." Menurut Sinambela, dkk (2012) mengemukakan bahwa kinerja pegawai didefinisikan sebagai kemampuan pegawai dalam melakukan sesuatu keahlian tertentu. Kinerja pegawai sangatlah perlu, sebab dengan kinerja ini akan diketahui seberapa jauh kemampuan pegawai dalam melaksanakan tugas yang dibebankan kepadanya. Untuk itu diperlukan penentuan kriteria yang jelas dan terukur serta ditetapkan secara bersama-sama yang dijadikan sebagai acuan.

Berdasarkan uraian tersebut di atas dengan pencatatan hasil kerja (proses) yang dicapai oleh seseorang karyawan dalam melakukan suatu pekerjaan dapat dievaluasi tingkat kinerja pegawainya, maka kinerja karyawan harus dapat ditentukan dengan pencapaian target selama periode waktu yang dicapai organisasi.

Standar kinerja merupakan tingkat kinerja yang diharapkan dalam suatu organisasi, dan merupakan pembanding (benchmarking) atau tujuan atau target tergantung pada pendekatan yang diambil. Standar kerja yang baik harus realistis, dapat diukur dan mudah dipahami dengan jelas sehingga bermanfaat baik bagi organisasi maupun para karyawan (Abdullah, 2014).

\section{Kecerdasan Emosi}

Istilah "kecerdasan emosi" (Emotional Quotient) pertama kali dilontarkan pada tahun 1990 oleh psikolog Peter Salovey dari Harvard University dan John Mayer dari University of New Hampshire untuk menerangkan kualitas-kualitas emosi yang tampaknya penting bagi keberhasilan. Salovey dan Mayer mendefinisikan kecerdasan emosional atau yang sering disebut Emotional Intelligence (EI) sebagai himpunan bagian dari kecerdasan sosial yang melibatkan kemampuan memantau perasaan sosial yang melibatkan kemampuan pada orang lain, memilah-milah semuanya dan menggunakan informasi ini untuk membimbing pikiran dan tindakan. Kecerdasan emosi sangat dipengaruhi oleh lingkungan, tidak bersifat menetap, dan dapat berubah-ubah setiap saat. Keterampilan EI bukanlah lawan keterampilan IQ atau keterampilan kognitif, namun keduanya berinteraksi secara dinamis, baik pada tingkatan konseptual maupun di dunia nyata. Gardner dalam bukunya yang berjudul "Frame Of Mind", mengatakan bahwa bukan hanya satu jenis kecerdasan monolitik yang penting untuk meraih sukses dalam kehidupan, melainkan ada spektrum kecerdasan yang lebar dengan 
tujuh varietas utama yaitu linguistik, matematika/logika, spasial, kinestetik, musik, interpersonal dan intrapersonal.

Dengan demikian kecerdasan emosi adalah kemampuan yang menuntut diri sendiri untuk belajar mengakui dan menghargai perasaan diri sendiri dan orang lain serta menanggapinya dengan tepat, menerapkan emosi dengan efektif dalam kehidupan dan pekerjaan seharihari, serta merupakan kemampuan seseorang untuk mengenali emosi diri, mengelola emosi, memotivasi diri sendiri, mengenali emosi orang lain (empati) dan kemampuan untuk membina hubungan (kerjasama) dengan orang lain.

\section{Komunikasi Terapeutik}

Komunikasi terapeutik adalah komunikasi yang direncanakan secara sadar, bertujuan dan kegiatannya dipusatkan untuk kesembuhan klien. Tehnik komunikasi terapeutik merupakan cara untuk membina hubungan yang terapeutik dimana menjadi penyampaian informasi dan pertukaran perasaan dan pikiran dengan maksud untuk mempengaruhi orang lain (Stuart \& Sudden, 2001). Komunikasi terapeutik adalah komunikasi yang terjadi antara perawat dengan klien anggota tim kesehatan lainnya. Komunikasi ini umumnya lebih akrab karena mempunyai tujuan, berfokus pada klien yang membutuhkan bantuan. Perawat secara aktif mendengarkan dan memberi respon kepada klien dengan cara menunjukkan sikap mau menerima dan mau memahami sehingga dapat mendorong klien untuk berbicara secara terbuka tentang dirinya. Selain itu membantu klien untuk melihat dan memperhatikan apa yang tidak disadari sebelumnya (Mukhripah, 2009).

\section{Pelatihan}

Pelatihan merupakan peroses membantu para tenaga kerja untuk memperoleh afektivitas dalam pekerjaan mereka yang sekarang atau yang akan datang melalui pengembangan kebiasaan tentang pikiran, tindakan, kecakapan, pengetahuan, dan sikap yang layak (Sastrohardiwiryo:2001).

Sedangkan menurut Rivai, (2010) pelatihan adalah proses secara sistematis mengubah tingkah laku pegawai untuk mencapai tujuan organisasi. Pelatihan berkaitan dengan keahlian dan kemampuan pegawai untuk melaksanakan pekerjaan saat ini. Pelatihan memiliki orientasi saat ini dan membantu pegawai untuk mencapai keahlian dan kemampuan tertentu agar berhasil dalam melaksanakan pekerjaannya.

Dengan demikian pelatihan adalah suatu kegiatan yang dilaksanakan oleh perusahaan dengan tujuan untuk meningkatkan, membantu dan memperbaiki dan pengetahuan karyawan.

\section{Kerangka PemikiranTeoritis}

Pengembangan model penelitian memberikan gambaran mengenai variabel variabel yang digunakan dalam penelitian

untuk melihat hubungan yang terjadi antar variabel (antara variabel independent dan dependent ). Dalam penelitian ini penulis kembangkan model sebagai berikut: 


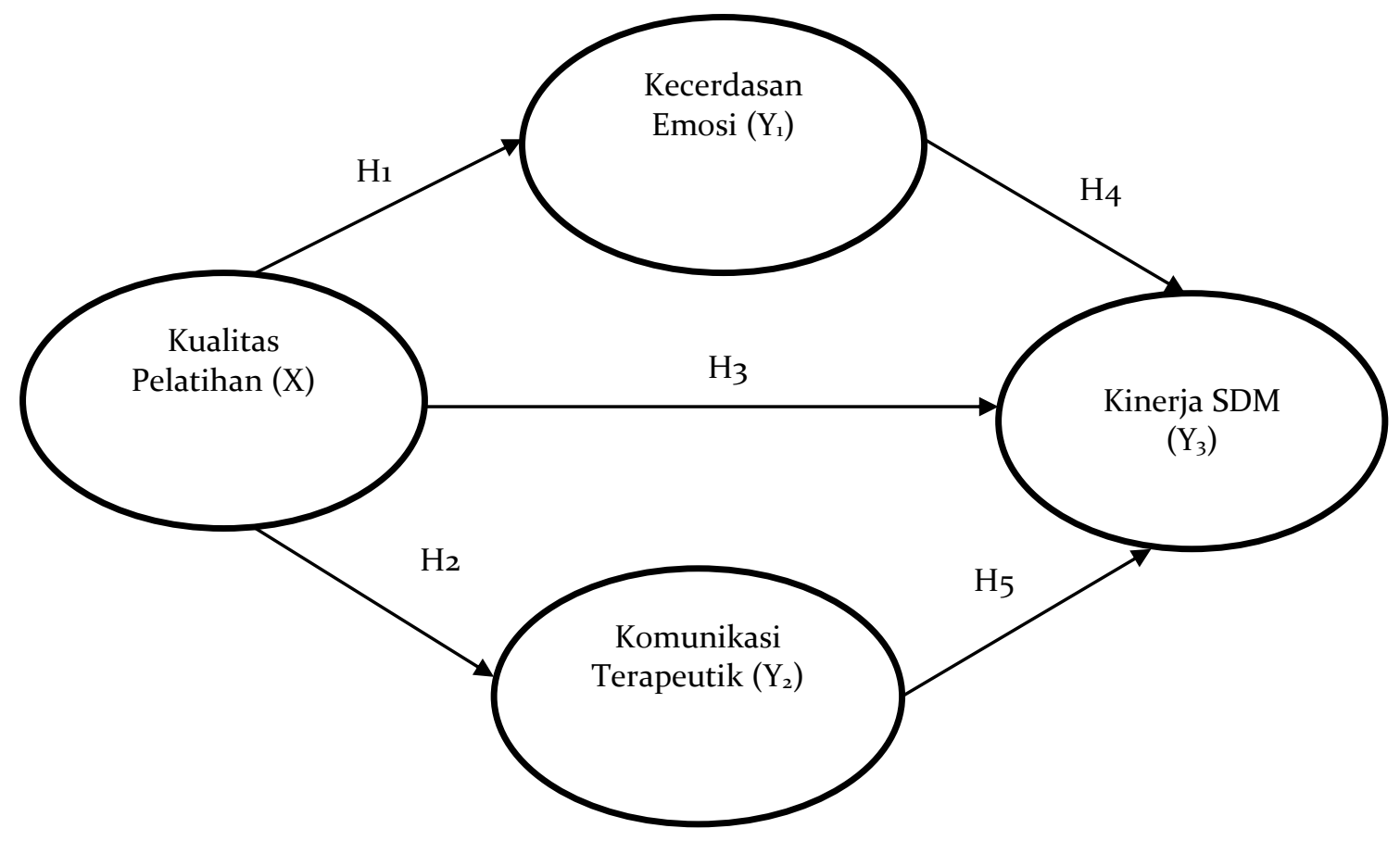

Gamnar 1

Kerangka Pemikiran Teoritas

\section{Hipotesis Penelitian}

$\mathrm{H}_{1}$ : Pelatihan berpengaruh positif dan signifikan terhadap Kecerdasan Emosi $\mathrm{H}_{2}$ : Pelatihan berpengaruh positif dan signifikan terhadap komunikasi terapeutik $\mathrm{H}_{3}$ : Pelatihan berpengaruh positif dan signifikan terhadap Kinerja SDM $\mathrm{H}_{4}$ : Kecerdasan Emosi berpengaruh positif terhadap Kinerja SDM $\mathrm{H}_{5}$ : Komunikasi Terapeutik berpengaruh positif terhadap Kinerja SDM

\section{METODE PENELITIAN}

\section{Variabel Penelitian dan Definisi Operasional Variabel}

Dalam penelitian ini terdapat tiga variable bebas dan dua variabel, yaitu: kualitas pelatihan $(\mathrm{X})$, kecerdasan emosi $\left(\mathrm{Y}_{1}\right)$, komunikasi terapeutik $\left(\mathrm{Y}_{2}\right)$, dan kinerja SDM $\left(\mathrm{Y}_{3}\right)$.

\section{Definisi Operasional Variabel dan Indikator}

Variabel dalam penelitian ini terdiri dari variabel bebas (independent) dan variabel terikat (dependent). Variabel tersebut terdiri dari variabel bebas yaitu: kualitas pelatihan, kecerdasan emosi, dan komunikasi terapeutik dan variabel terikat yaitu kinerja. 


\section{Populasi dan Samel \\ Populasi}

Populasi dalam penelitian ini adalah keseluruhan pegawai di Panti Pelayanan Sosial Lanjut Usia "Potroyudan" Jepara dan Panti Pelayanan Sosial Lanjut Usia "Turusgede" Rembang sebanyak 57 pegawai.

\section{Sampel}

Metode sample yang digunakan yaitu sampel total (total sampling) atau sensus. Metode total sampling ini dipakai

karena populasi relatif kecil (mudah

dijangkau). Sampel dalam penelitian ini adalah 57 pegawai Panti Pelayanan Sosial Lanjut Usia "Potroyudan" Jepara dan Panti Pelayanan Sosial Lanjut Usia “Turusgede"

Rembang, yang merupakan Panti Pelayanan Sosial Tipe A.

\section{Tehnik Analisis Data Uji Validitas}

Uji validitas digunakan untuk mengukur sah atau valid tidaknya suatu kuesioner. Suatu kuesioner dikatakan valid jika pertanyaan pada kuesioner mampu untuk mengungkapkan sesuatu yang akan diukur oleh kuesioner, (Ghozali, 2005). Apabila nilai korelasi yang dihasilkan signifikan, dimana nilai probabilitas yang d

iperoleh lebih dari nilai $\alpha=0,05$ maka instrumen pertanyaan tersebut valid sebagai alat ukur.

\section{Uji Reliabilitas}

Uji reliabilitas dilakukan untuk mengetahui sejauh mana pengukuran suatu kuesioner yang dikatakan handal jika jawaban yang diberikan responden terhadap pertanyaan adalah konsisten atau pengukuran memberikan hasil yang relatif tidak berbeda apabila dilakukan pengukuran kembali pada subyek yang sama dari waktu kewaktu, (Singgih Santoso, 2002). Variabel dikatakan reliabel jika memberi nilai Cronbach $\alpha>0,6$ (Ghozali, 2005).

\section{Uji Normalitas}

Uji normalitas ini bertujuan untuk mengetahui setelah perlakuan akan berdistribusi normal atau tidak. Untuk uji normalitas data hasil tes digunakan uji normal probability plot melalui tampilan output SPSS.

\section{Uji Multikolinearitas}

Uji multikolinearitas bertujuan untuk menguji apakah model regresi ditemukan adanya korelasi antar variable bebas (independent). Windows. Jika dari matrik korelasi antar variable bebas ada korelasi yang tinggi (umumnya di atas 0,90), maka hal ini merupakan indikasi adanya multikolinearitas, dan sebaliknya. Sedangkan menurut Singgih (2001) VIF mempunyai persamaan , dan pada umumnya jika VIF lebih dari 5, maka variable tersebut mempunyai persoalan multikolinearitas dengan variable bebas yang lainnya.

\section{Uji Heterokedastisitas}

Uji asumsi heterokedastisitas untuk menguji dalam sebuah model regresi apakah terjadi ketidaksamaan varians dari residual dari satu pengamatan ke pengamatan lain. 


\section{Uji Persamaan Regresi}

Analisis ini digunakan untuk mencari persamaan regresi atau pengaruh antara kualitas pelatihan $\left(\mathrm{X}_{1}\right)$, kecerdasan emosi $\left(\mathrm{Y}_{1}\right)$, komunikasi terapeutik $\left(\mathrm{Y}_{2}\right)$, dan Kinerja SDM $\left(\mathrm{Y}_{3}\right)$. Adapun rumus yang dipakai yaitu :

$\mathrm{Y}_{1}=\mathrm{b}_{1} \mathrm{X}+\mathrm{e}_{1}$

$\mathrm{Y}_{2}=\mathrm{b}_{2} \mathrm{X}+\mathrm{e}_{2}$

$\mathrm{Y}_{3}=\mathrm{b}_{3} \mathrm{X}+\mathrm{b}_{4} \mathrm{Y}_{1}+\mathrm{b}_{5} \mathrm{Y}_{2}+\mathrm{e}_{3}$

Keterangan :

$\mathrm{Y}_{1} \quad=$ Kecerdasan Emosi

$\mathrm{Y}_{2}=$ Komunikasi Terapeutik

$\mathrm{Y}_{3}=$ Kinerja

$\mathrm{X}=$ Kualitas Pelatihan

$\mathrm{a} \quad=$ konstanta

$\mathrm{b} \quad=$ koefisien regresi

Jika angka probabilitas hasil analisis $\leq 0,05$ maka hipotesis nol (Ho) ditolak dan hipotesis kerja (Hk) diterima. Selain analisis regresi juga dilakukan Uji t. Nilai thitung dikatakan signifikan apabila hasilnya $>2$.

\section{Uji Hipotesis}

\section{Uji t (parsial)}

Menunjukkan apakah variabel Independen secara partial atau individual berpengaruh signifikan terhadap variabel dependennya. Menurut Ghozali (2009:324) uji t pada dasarnya menunjukkan seberapa jauh pengaruh satu variabel bebas secara individual dalam menerangkan variasi variabel terikatnya. Apabila pada taraf signifikansi $0,05 \%$, nilai probabilitas $<5 \%$ maka hipotesis diterima, berarti ada pengaruh diantara dua variabel yang diuji, sebaliknya, apabila nilai probabilitas $>5 \%$, maka hipotesis ditolak, berarti tidak ada pengaruh antara dua variabel.

\section{Uji Intervening}

Variabel intervening merupakan variabel penyela yang terletak di antara variabel dependen dan variabel independen. Tujuan dari variabel intervening ini adalah untuk menguji pengaruh langsung dan pengaruh tidak langsung antara variabel indepen terhadap variabel dependen.

\section{Koefisien Determinasi}

Koefisien determinasi $\left(\mathrm{R}^{2}\right)$ merupakan alat untuk mengurut seberapa jauh kemampuan model dalam menerangkan variasi variabel dependen. Nilai koefisien determinasi adalah antara nol atau satu. Nilai R2 yang kecil berarti kemampuan variabel-variabel independen dalam menjelaskan variasi variabel dependen amat terbatas. Dan sebaliknya jika nilai yang mendekati 1 berarti variabel-variabel independen memberikan hampir semua informasi yang dibutuhkan untuk memprediksi variabel-variabel dependen. 


\section{ANALISIS DATA DAN PEMBAHASAN}

Populasi dalam penelitian ini sebesar 57pegawai di panti pelayanan sosial lanjut usiadinas sosial provinsi Jawa Tengah. Metode sample yang digunakan yaitu sampel total (total sampling) atau sensus. Metode total sampling ini dipakai karena populasi relatif kecil (mudah dijangkau). Sampel dalam penelitian ini adalah 57 pegawai Panti Pelayanan Sosial Lanjut Usia "Potroyudan" Jepara dan Panti Pelayanan Sosial Lanjut Usia "Turusgede" Rembang..

Jumlah responden dengan usia 20 - 24 tahun sebanyak 1 orang atau 1,75\%, 25 - 29 tahun sebanyak 5 orang atau 8,77 \%, 30 - 34 tahun sebanyak 6 orang atau 10,53 $\%, 35$ - 39tahun sebanyak 10 orang atau 17,54\%, usia40 - 44 sebanyak14 orang atau $24,56 \%$, usia 45 - 49 tahun sebanyak 19 orang atau 33,33\%, usia50 - 54 tahun sebanyak 2 orang atau 3,5\%. Mayoritas responden berusia 40 tahun sampai 49 tahun dengan prosentase sebesar $57,89 \%$ kalau dilihat dari umur responden mayoritas sudah berusia 40 ke atas, sehingga memiliki keterbatasan dalam memberikan pelayanan dan apabila diberikan pelatihan perlu diberikan pelatihan yang sesuai dengan kecakapan dari responden.

Sedangkan responden berdasarkan kelamin, laki-laki sebanyak 28 orang atau 49,12\%, perempuan sebanyak 29 orang 50,88 \%. Responden antar laki-laki dan perempuan dalam penelitian ini hampir seimbang tidak ada perbedaan gender antara laki-laki dan perempuan.

Responden berdasarkan masa kerja, jumlah responden dengan masa kerja $0-4$ tahun sebanyak 1 orang atau 1,75\%, 5 - 9 tahun sebanyak 2 orang atau 3,5\%, $10-14$ tahun sebanyak 5 orang atau $8,77 \%$, masa kerja 15 - 19 tahun sebanyak 10 orang atau $17,54 \%$, masa kerja20 - 24 tahun sebanyak 11 orang atau 19,29 \%, masa keja $25-29$ tahun sebanyak 13 orang atau $22,8 \%$, masa keja $30-34$ tahun sebanyak 15 orang atau $26,35 \%$.

Berdasarkan pendidikan, responden dengan pendidikan SD sebanyak 1 orang atau 1,75\%, pendidikan SLTP sebanyak 3 orang atau 5,26\%, SLTA sebanyak 15 orang atau 26,31\%, diploma sebanyak 16 orang atau28,07\%, Sarjana (S1) sebanyak 18 orang atau $31,58 \%$ dan Pascasarjana (S2) sebanyak 4 orang atau 7,03\%. Hasil rekapitulasi responden berdasarkan pendidikan mayoritas responden berpedidikan D1 sampai dengan S1 dengan prosentase sebesar 59,65\%, kalau dilihat dari pendidikan responden memiliki tingat pendidikan yang cukup tinggi namun dalam memberikan pelayanan sosial disamping pendidikan tinggi juga perlu didukung dengan ilmu sosial dan latar belakang sosial.

Berdasarkan golongan, jumlah responden dengan golongan IV sebanyak 3 orang atau 5,26\%, golongan III sebanyak 40 orang atau 59,64\%, golongan II sebanyak 16 orang atau $28,07 \%$, golongan I sebanyak 4 orang atau 7,03 \%.

\section{Uji Validitas}

Uji validitas dilakukan dengan bantuan komputer program SPSS versi 15 teknik product moment. Dari hasil pengujian menunjukkan bahwa pada pengujian validitas untuk masing-masing variabel di atas adalah valid. Hal ini dibuktikan dengan semua nilai $r$ hitung pada indikator variabel tersebut diperoleh melebihi $r$ tabel sebesar 0,05 , sehingga masing-masing indikator dapat dilakukan langkah pengujian berikutnya. 


\section{Uji Reliabilitas}

Uji reliabilitas merupakan pengujian dilakukan untuk mengetahui apakah variabel tersebut dapat dipercaya untuk dilakukan pada pengujian selanjutnya. Berdasarkan hasil pengolahan data dapat diketahui bahwa masing-masing variabel ternyata diperoleh nilai $\mathrm{r}$ alpha lebih besar dari nilai standarisasi atau batas yang ditentukan yaitu 0,600.Dengan demikian, hasil uji reliabilitas terhadap keseluruhan variabel adalah reliabel.

\section{Uji asumsi klasik}

\section{Uji Normalitas}

Uji normalitas ini bertujuan untuk mengetahui setelah perlakuan akan berdistribusi normal atau tidak. Untuk uji normalitas data hasil tes digunakan uji normal probability plot melalui tampilan output SPSS. Dari hasil uji Normalitas One-Sample Kolmogorov-Smirnov Test, disimpulkan bahwa nilai sig Kolmogorov-Smirnov Z lebih dari 0,05. Sehingga persyaratan normalitas dapat dipenuhi.

\section{Uji Multikolinieritas}

Uji multikolinieritas bertujuan untuk menguji apabila model regresi ditemukan adanya korelasi antar variabel bebas. Default SPSS bagi angka tolerance adalah 0,10, artinya bahwa semua variabel yang akan dimasukkan dalam perhitungan model regresi harus mempunyai tolerance di atas 0,10. Apabila ternyata lebih rendah dari 0,10 dapat dikatakan terjadi multikolinieritas. Sedangkan pada Variance Inflation Factor (VIF), pada umumnya VIF ditentukan kurang dari 10. Artinya apabila variabel tersebut lebih dari 10 maka mempunyai persoalan multikolinieritas (korelasi yang besar diantara variabel bebas) dengan variabel bebas lainnya. Begitu juga sebaliknya apabila variabel tersebut kurang dari 10 maka menunjukka tidak terdapat multikolinieritas (Ghozali, 2009:95). Dari hasil pengujian dapat disimpulkan disimpulkan bahwa nilai VIF dari variabel lebih kecil dari 10 dan nilai tolerance lebih besar dari 0,10 . Hal ini berarti tidak terjadi multikolinieritas dalam model regresi penelitian ini.

\section{Uji Heteroskedastisitas}

Uji asumsi heterokedastisitas untuk menguji dalam sebuah model regresi apakah terjadi ketidaksamaan varians dari residual dari satu pengamatan ke pengamatan lain. Jika varians dari residual dari satu pengamatan ke pengamatan lain tetap, maka disebut Homoskedastisitas. Dan jika varians berbeda, disebut heterokedastisitas. Model regresi yang baik adalah tidak terjadi heterokedastisitas (Singgih, 2002). Hasil Uji Heteroskedasitas diketahui bahwa uji ini tidak terjadi problem heteroskedastisitas.

\section{Regresi Linier Berganda}

Analisis ini digunakan untuk mencari persamaan regresi atau pengaruh antara gaya kepemimpinan, karakter individu, lingkungankerja dan disiplinterhadap kinerja Adapun rumus yang dipakai yaitu.

$$
\begin{aligned}
& Y_{1}=b_{1} X+e \\
& Y_{2}=b_{2} X+e \quad(1) \\
& Y_{3}=b_{3} X+b_{4} Y_{1}+b_{5} Y_{2}+e
\end{aligned}
$$

Keterangan:

$\mathrm{Y}_{3}=$ kinerja 
$\mathrm{Y}_{1}=$ kecerdasan emosi.

$\mathrm{Y}_{2}=$ komunikasi terapuetik

$\mathrm{b}=$ Koefisien regresi variabel gaya kepemimpinan

$\mathrm{X}=$ kualitas pelatihan

Dari hasil Regresi Linier Berganda, dapat diketahui bahwa :

- Dependent Variabble : $\mathrm{Y}_{1}$

$\mathrm{Y}_{1}=0,642 \mathrm{X}$

Keterangan :

$\mathrm{Y}_{1}=$ Kecerdasan Emosi

$\mathrm{X}=$ Kualitas Pelatihan

- Dependent Variable: $\mathrm{Y}_{2}$

$\mathrm{Y}_{2}=0,618 \mathrm{X}$

Keterangan :

$\mathrm{Y}_{1} \quad=$ Kecerdasan Emosi

$\mathrm{Y}_{2}=$ Komunikasi Terapeutik

$\mathrm{X}=$ Kualitas Pelatihan

- Dependent Variable: $\mathrm{Y}_{3}$

$\mathrm{Y}_{3}=0,263 \mathrm{X}+0,515 \mathrm{Y}_{1}+0,223 \mathrm{Y}_{2}$

Keterangan :

$\mathrm{Y}_{1} \quad=$ Kecerdasan Emosi

$\mathrm{Y}_{2}=$ Komunikasi Terapeutik

$\mathrm{Y}_{3}=$ Kinerja

$\mathrm{X} \quad=$ Kualitas Pelatihan

\section{Pengujian Hipotesis}

\section{Uji t}

Dalam hasil penelitian diperoleh Hasil Uji t sebagai berikut:

- Dependent Variable: Y1

1. Pengujian hipotesis 1

Pengaruhantara kualitas pelatihan dengan kecerdasan emosi

H0 : $\quad$ Tidak ada Pengaruh antara kualitas pelatihan dengan kecerdasan emosi.

H1 : Ada Pengaruhantara kualitas pelatihan dengan kecerdasan emosi.

Didasarkan hasil analisis diketahui bahwa nilai $0,00<0,05$ sehingga $\mathrm{H} 1$ diterima. Artinya, ada pengaruh signifikan antara kualitas pelatihan dengan kecerdasan emosi. Dengan hasil nilai positif maka dapat dikatakan bahwa kualitas pelatihan ditingkatkan maka kecerdasan emosi juga akan meningkat.

- Dependent Variable: $\mathrm{Y}_{2}$

2..Pengujian hipotesis 2

Pengaruh antara kualitas pelatihan dengan komunikasi terapeutik.

$\mathrm{H}_{0} \quad$ : Tidak ada Pengaruh antara kualitas pelatihan dengan komunikasi terapeutik.

$\mathrm{H}_{2} \quad$ : Ada Pengaruhantara kualitas pelatihan dengan komunikasi terapeutik.

Didasarkan hasil analisis diketahui bahwa nilai sig. 0,000 $<0,05$ sehingga $\mathrm{H}_{2}$ diterima.

Artinya,ada pengaruh signifikan antara kualitas pelatihan dengan komunikasi terapeutik, 
artinya jika kualitas pelatihan ditingkatkan maka akan semakin meningkat pula komunikasi terapeutik.

\section{Pengujian hipotesis 3}

Pengaruh antara kecerdasan emosi dengan komunikasi terapeutik.

$\mathrm{H}_{0} \quad$ : Tidak ada pengaruh signifikan antara kecerdasan emosi dengan komunikasi terapeutik.

$\mathrm{H}_{3}$ : Ada pengaruh signifikan antara kecerdasan emosi dengan komunikasi terapeutik.

Didasarkan hasil analisis diketahui bahwa nilai sig. 0,270>0,05 sehingga $\mathrm{H}_{3}$ ditolak dan $\mathrm{H}_{0}$ diterima. Artinya, tidak ada pengaruh signifikan antara kecerdasan emosi dengan komunikasi terapeutik.

- Dependent Variable:

4. Pengujian Hipotesis 4

Pengaruh kualitas pelatihan dengan Kinerja.

$\mathrm{H}_{0} \quad$ : Tidak ada pengaruh signifikan antara kualitas pelatihan dengan Kinerja.

$\mathrm{H}_{4} \quad$ : Ada pengaruh signifikan antara kualitas pelatihan dengan Kinerja.

Didasarkan hasil analisis data diketahui bahwa nilai signifikansi 0,016 $<0,05$ sehingga $\mathrm{H}_{4}$ diterima. Artinya, ada pengaruh signifikan antara kualitas pelatihan dengan Kinerja, maka jika kualitas pelatihan ditingkatkan akan semakin meningkat pula kinerjanya.

5.Pengujian hipotesis 5

Pengaruh kecerdasan emosi dengan Kinerja.

$\mathrm{H}_{0} \quad$ : Tidak ada pengaruh signifikan antara kecerdasan emosi dengan Kinerja

$\mathrm{H}_{5} \quad$ : Ada pengaruh signifikan antara kecerdasan emosi dengan Kinerja

Didasarkan hasil analisis diketahui bahwa nilai sig. 0,000<0,05 sehingga $\mathrm{H}_{0}$ ditolak dan H5 diterima. Artinya, ada pengaruh signifikan antara kecerdasan emosi dengan kinerja, artinya bila kecerdasan emosi ditingkatkan maka kinerja juga akan meningkat.

\section{Pengujian hipotesis 6}

Pengaruh antara komunikasi terapuetik dengan Kinerja.

$\mathrm{H}_{0} \quad$ : Tidak ada pengaruh signifikan antara komunikasi terapuetik dengan Kinerja.

$\mathrm{H}_{6} \quad$ : Ada pengaruh signifikan antara antara komunikasi terapuetik dengan Kinerja.

Didasarkan hasil analisis data diketahui bahwa nilai sig. $0,023<0,05$ sehingga $\mathrm{H}_{6}$ diterima. Artinya, ada pengaruh signifikan antara komunikasi terapuetik dengan kinerja, artinya jika komunikasi terapeutik ditingkatkan maka kinerja juga akan meningkat.

\section{Uji f}

Kualitas pelatihan, kecerdasan emosi dan komunikasi terapeutik secara bersama-sama berpengaruh terhadap kinerja. Hasil uji $\mathrm{F}$ diperoleh nilai signifikan $0,000(\operatorname{sig}<\alpha 0,05)$ hasil ini memperlihatkan bahwa model mampu secara signifikan dalam menjelaskan fenomena sejauh mana variabel Kualitas pelatihan, kecerdasan emosi dan komunikasi terapeutik secara bersama-sama berpengaruh terhadap kinerja.

\section{Koefisien Determinasi}

Digunakan untuk mengetahui presentase besarnya perubahan variabel tergantung yang disebabkan oleh perubahan variabel bebas. (Sudjana, 1997:383). Rumus

$\mathrm{FP} \quad=\mathrm{R}^{2}$ 
FP $\quad=$ koefisien determinasi

$\mathrm{R}^{2} \quad=$ kuadrat dari nilai koefisien korelasi

Koefisien determinasi (Adjusted $\mathrm{R}^{2}$ ) pada intinya mengukur seberapa jauh kemampuan model dalam menerangkan variasi variabel dependen. Hasil regresi menunjukkan Adjusted $\mathrm{R}^{2}$ sebesar 0,750 berarti bahwa $75 \%$ variasi partisipasi dapat dijelaskan oleh variasi dari ketiga variabel independen. Sedangkan sisanya sebesar $(100 \%-75 \%)$ atau $25 \%$ dijelaskan oleh sebab-sebab yang lain di luar model.

\section{Pembahasan}

1.Hubungan antara kualitas pelatihan dengan kecerdasan emosi

Pelatihan merupakan upaya meningkatkan kualitas kemampuan yang menyangkut kemampuan kerja, berpikir dan keterampilan dan pendidikan dan pelatihan bagi karyawan merupakan unsur yang terpenting dengan pengembangan sumber daya manusia, guna meningkatkan kemampuan kerja karyawan san selanjutnya produktivitas organisasi.

\section{Hubungan antara kualitaspelatihan dengan komunikasi terapeutik}

Pelatihan adalah proses secara sistematis mengubah tingkah laku pegawai untuk mencapai tujuan organisasi. Pelatihan berkaitan dengan keahlian dan kemampuan pegawai untuk melaksanakan pekerjaan saat ini. Pelatihan memiliki orientasi saat ini dan membantu pegawai untuk mencapai keahlian dan kemampuan tertentu agar berhasil dalam melaksanakan pekerjaannya. Apabila komunikasi terapeutik kurang dipunyai oleh seorang pegawai, maka perlu dilakukan suatu pelatihan untuk meningkatkan komunikasi terapeutik yang dimiliki oleh seorang pegawai.

\section{Hubungan antara kualitas pelatihan dengan kinerja}

Untuk dapat memperoleh kinerja yang baik, maka berarti kemampuan dan keterampilan yang dimiliki oleh para karyawan perusahaan harus baik pula, dan hal ini akan terjadi jika diadakan pelatihan yang ditujukan untuk para karyawan. Seperti kita ketahui bahwa latihan kerja atau pelatihan merupakan kegiatan perusahaan dengan maksud dapat memperbaiki dan mengembangkan sikap, tingkah laku, keterampilan, dan pengetahuan para karyawan sesuai keinginan perusahaan yang bersangkutan. Apabila karyawan telah dilatih maka mereka akan memiliki kemampuan dan keterampilan lebih baik, sehingga mereka mampu bekerja lebih efektif dan efisien, dan akhirnya karyawan tersebut mendapat penilaian kerja yang baik pula. Pelatihan adalah suatu kegiatan untuk memperbaiki kemampuan kerja karyawan dalam memahami suatu pengetahuan praktis dan penerapannya guna meningkatkan keterampilan, kecakapan dan sikap yang diperlukan organisasi dalam mencapai tujuan yang juga disesuaikan dengan tuntutan pekerjaan yang akan diemban oleh seorang karyawan. Jadi pelatihan dan kinerja mempunyai hubungan yang sangat erat karena untuk dapat mencapai kinerja yang tinggi sangat ditentukan oleh adanya kemampuan dan keterampilan serta pengetahuan karyawan yang tinggi pula dari hasil pelatihan.

Pelaksanaan kerja dalam arti kinerja tidakhanya menilai fisik yang telah dihasilkan oleh seorang karyawan. Pelaksanaan pekerjaan disini dalam artian secara keseluruhan, sehingga dalam penilaian kinerja ditunjukkan pada berbagai bidang seperti kemampuan kerja, kerajinan, hubungan kerja, prakarsa, kepemimpinan atau hal-hal khusus sesuai dengan bidang dan level pekerjaan yang dijabatnya. Oleh karena itulah penilaian kinerja 
secara rutin perlu dilakukan agar diketahui peranan aktif para karyawan dalam mendukung tercapainya tujuan perusahaan.

\section{Hubungan antara Kecerdasan Emosi terhadap Kinerja}

Kecerdasan emosional merupakan kemampuan mencakup pengendalian diri, semangat, ketekunan, serta kemampuan untuk memotivasi diri sendiri. Pengaruh kecerdasan emosional pada kinerja positif, artinya semakin tinggi kecerdasan emosional seseorang maka semakin tinggi kinerja karyawan. Sebaliknya, semakin rendah kecerdasan emosional maka semakin rendah kinerja karyawan.

\section{Hubungan antara Komunikasi Terapeutik terhadap Kinerja}

Komunikasi terapeutik merupakan cara yang efektif untuk mempengaruhi tingkah laku manusia dan bermanfaat dalam melaksanakan pelayanan, sehingga komunikasi harus dikembang secara terus menerus. Hubungaan antara pemberi pelayanan dan penerima manfaat yang terapeutik bisa terwujud dengan adanya interaksi yang terapeutik antar keduanya, interaksi tersebut harus dilakukan dengan tahapan-tahapan baku interaksi terapeutik, tahapan itu antara lain tahap preorientasi, tahap orientasi, tahap kerja, dan tahap terminasi.

Komunikasi terapeutik merupakan cara untuk membina hubungan yang terapeutik dimana terjadi penyampaian informasi dan pertukaran perasaan dan pikiran dengan maksud untuk mempengaruhi orang lain, komunikasi ini direncanakan dengan sadar, bertujuan, dan kegiatannya dipusatkan untuk kesembuhan pasien. Komunikasi terapeutik adalah kemampuan atau keterampilan perawat untuk membantu klien beradaptasi terhadap stress, mengatasi psikologis, dan belajar bagaimana berhubungan dengan orang lain.

\section{PENUTUP \\ Kesimpulan}

Dari beberapa bab terdahulu dan hasil penelitian yang sudah dilakukan pada dapat diambil kesimpulan sebagai berikut:

1) Didasarkan pada hasil analisis maka terdapat pengaruh signifikan antara kualitas pelatihan dengan kecerdasan emosi, artinya semakin ditingkatkan kualitas maka akan semakin meningkat kecerdasarn emosi seseorang; 2) Didasarkan pada hasil analisis ada pengaruh signifikan antara kualitas pelatihan dengan komunikasi terapeutik, artinya semakin ditingkatkan kualitas pelayanan maka akan semakin meningkat pula komunikasi terapeutik seseorang; 3) Dari hasil penelitian tidak ada pengaruh signifikan antara kecerdasan emosi dengan komunikasi terapeutik, artinya walaupun kecerdasan emosi ditingkatkan tidak akan mempengaruhi komunikasi terapeutik 4) Berdasarkan hasil penelitian pengaruh signifikan antara kualitas pelatihan dengan kinerja, artinya jika kualitas pelatihan ditingkatkan akan semakin meningkat pula kinerja;5)Dari hasil penelitian dapat dilihat bahwa ada pengaruh signifikan antara kecerdasan emosi dengan kinerja, artinya bila kecerdasan emosi ditingkatkan maka kinerja juga akan meningkat; 6) Dari hasil penelitian dapat dilihat bahwa ada pengaruh signifikan antara komunikasi terapuetik dengan kinerja, artinya jika komunikasi terapeutik ditingkatkan maka kinerja juga akan meningkat pula. 


\section{Implikasi Teori}

Implikasi teoritis penelitian ini berkaitan dengan teori pelatihan, kecerdasarn emosi dan komuikasi terapeutik terutama dalam meningkatkan kinerja Panti Pelayanan Sosial Lanjut Usia Dinas Sosial Provinsi Jawa Tengah. Implikasi tersebut dapat dijelaskan sebagai berikut:

1.Implikasi yang berkenaan dengan teori kinerja, Abdullah, (2014) memberikan pengertian bahwa kinerja merupakan hasil pekerjaan yang mempunyai hubungan kuat dengan tujuan strategi organisasi, kepuasan konsumen dan memberikan kontribusi ekonomi.

2.Implikasi yang berkenaan dengan teori kecerdasan emosi, kecerdasan emosional (Emotional Intelligence) adalah kemampuan seseorang untuk mendeteksi serta mengelola petunjuk-petunjuk dan informasi emosional. Kecerdasan emosi merupakan kemampuan seseorang untuk mengendalikan emosi dirinya sendiri dan orang lain, membedakan satu emosi dengan lainnya, dan menggunakan emosi tersebut untuk menuntun proses berfikir serta perilaku seseorang.

3.Implikasi yang berkenaan dengan teori komunikasi terapeutik, komunikasi terapeutik adalah komunikasi yang direncanakan secara sadar, bertujuan dan kegiatannya dipusatkan untuk kesembuhan klien. Tehnik komunikasi terapeutik merupakan cara untuk membina hubungan yang terapeutik dimana menjadi penyampaian informasi dan pertukaran perasaan dan pikiran dengan maksud untuk mempengaruhi orang lain. Komunikasi ini umumnya lebih akrab karena mempunyai tujuan, berfokus pada klien yang membutuhkan bantuan

4.Implikasi yang berkenaan dengan teori pelatihan, pelatihan adalah proses secara sistematis mengubah tingkah laku pegawai untuk mencapai tujuan organisasi. Pelatihan berkaitan dengan keahlian dan kemampuan pegawai untuk melaksanakan pekerjaan saat ini.

\section{Implikasi Manajerial}

Penelitian ini diharapkan dapat memberikan berbagai manfaat bagi pihak-pihakyang terkait, antara lain:

1.Hasil penelitian yang menunjukkan bahwa terdapat pengaruh signifikan antara kualitas pelatihan terhadap keserdasarn emosi, mengandung implikasi bahwa agar kecerdasan emosi meningkat secara signifikan maka kemungkinan perlu ditingkatkan dan diperhatikan kualitas pelatihan, hal ini dapat diterapkan pada Panti Pelayanan Sosial Lanjut Usia "Protoyudan" Jepara dan "Turus Gede" Rembang.

2.Untuk meningkatkan komunikasi terapeutik pegawai Panti Pelayanan Sosial Lanjut Usia "Protoyudan" Jepara dan "Turus Gede" Rembang dimungkinkan untuk lebih meningkatkan kualitas pelatihan. Pengembangan komunikasi terapeutik dapat dilakukan dengan pelatatihan misalkan dengan memberikan Workshop maupun in house traing, hal ini lebih bisa diterapkan dalam pengembangan komunikasi terapeutik.

3.Kecerdasan emosi terbukti tidak berpengaruh yang signifikan terhadap kecerdasan emosi, hal ini mengandung implikasi bahwa agar komunikasi terapeutik meningkat secara signifikan maka kemungkinan bukan aspek kecerdasan emosi saja yang perlu ditingkatkan dan diperhatikan, sehingga perlu dicari aspek-aspek lain yang kemungkinan bisa meningkatkan komunikasi terapeutik pegawai Panti Pelayanan Sosial Lanjut Usia "Protoyudan" Jepara dan "Turus Gede" Rembang 
4.Hasil penelitian menunjukkan bahwa ada pengaruh signifikan antara kualitas pelatihan dengan kinerja, hal ini mengandung implikasi bahwa untuk meningkatkan kinerja pegawai Panti Pelayanan Sosial Lanjut Usia "Protoyudan" Jepara dan "Turus Gede" Rembang perlu diperhatikan dan ditingkat kualitas pelatihan. Untuk meningkatkan kinerja SDM maka perlu dilakukan pelatihan-pelatihan seperti Bintek maupun pelatihan pelayanan yang disesuaikan dengan tugas pokok yang ada di Panti Pelayanan Sosial Lanjut Usia "Protoyudan" Jepara dan "Turus Gede" Rembang.

5.Hasil penelitian selanjutnya menunjukkan bahwa adanya pengaruh signifikan antara kecerdasarn emosi dengan kinerja pegawai, hal ini mempunyai implikasi bahwa untuk meningkatkan kinerja pegawai Panti Pelayanan Sosial Lanjut Usia "Protoyudan" Jepara dan "Turus Gede" Rembang perlu terus dikembangkan dan ditingkatkan kecerdasan emosi pegawai Panti Pelayanan Sosial Lanjut Usia "Protoyudan" Jepara dan "Turus Gede" Rembang.

6.Didasarkan hasil penelitian menunjukkan bahwa adanya pengaruh signifikan antara komunikasi terapeutik dengan kinerja, hal ini mempunyai implikasi bahwa untuk meningkatkan kinerja pegawai Panti Pelayanan Sosial Lanjut Usia "Protoyudan" Jepara dan "Turus Gede" Rembang maka perlu di tingkatkan komunikasi terapeutik. Komunikasi terapeutik lebih pada bagaimana memberikan dan menyampaikan komunikasi serta membina hubungan baik, maka untuk meningkatkan kinerja perlu didasari dengan komunikasi terapeutik.

\section{DAFTAR PUSTAKA}

Abdullah M. Ma'ruf. 2014. Manajemen dan Evaluasi Kinerja Karyawan. Yogyakarta : Penerbit Aswaja Pressindo

Asri Laksmi Riani, M. (2011).Perspektif Kompensasi. Surakarta: Yuma Pustaka.

Badeni. 2013. Kepemimpinan dan Prilaku Organisasi. Bandung: Alfabeta

Basu Swastha, Hani Handoko. 2011. Manajemen Pemasaran-Analisis Perilaku Konsumen. Yogyakarta: BPFE.

Guritno, Bambang dan Waridin, 2005.Pengaruh Persepsi Karyawan Mengenai Perilaku Kepemimpinan, Kepuasan Kerja dan Motivasi Terhadap Kinerja JRBI. Vol. 1

Khaliq, Ahmad, dkk.. 2014. "Identifying Financial Distress Firms: A Case Study of Makaysia's Goverrnment Linked Companies (GLC)", International Journal of Economics, Finance and Management, Vol.3

Moeheriono.(2012). Pengukuran Kinerja Berbasis Kinerja, Edisi Revisi. Jakarta: PT.Raja Grafindo Persada.

Rani Mariam, 2009, Pengaruh Gaya Kepemimpinan Dan Budaya Organisasi Terhadap Kinerja Karyawan Melalui Kepuasan Kerja Karyawan Sebagai Variabel 
Intervening Studi Pada Kantor Pusat PT. Asuransi Jasa Indonesia (Persero), Tesis,Universitas Diponegoro Semarang.

Robbins, Stephen P. dan Timothy A. Judge. 2008. Perilaku Organisasi Edisi ke-12, Jakarta: Salemba Empat.

Sebagai Variabel Moderating”. Tesis di Universitas Widayatama Bandung.

Sutrisno Edy Dr, M.Si. 2010. Manajemen Sumber Daya Manusia, Jakarta : Kencana Predana Media Grup

Thoha, Miftah. 2005. Perilaku Organisasi : Konsep Dasar dan Aplikasinya. Jakarta: Raja Grafindo Persada.

Trisnaningsih, S. 2007. Independensi Auditor dan Komitmen Organisasi Sebagai Mediasi Pengaruh Pemehaman Good Governance, Gaya Kepemimpinan dan Budaya Organisasi Terhadap Kinerja Auditor. Simposium Nasional Akuntansi X, Makasar.

Wibowo. 2007. Manajemen Kinerja. PT. Raja Grafindo Parsada: Jakarta.

Wirawan. 2009. Evaluasi Kinerja Sumber Daya Manusia : Teori Aplikasi dan Penelitian. Jakarta: Salemba Empat.

Baharuddin dan Wahyuni, (2015), Teori belajar dan pembelajaran (Yogyakarta: ARRUZZ MEDIA)

Veitzal Rivai. (2010). Manajemen Sumber Daya Manusia untuk Perusahaan. Jakarta: PT. Raja Grafindo Persada 